\title{
ACTINIUM ABUNDANCES IN STELLAR ATMOSPHERES
}

\author{
V. Yushchenko ${ }^{1,2}$, V. Gopka ${ }^{1}$, A. Yushchenko ${ }^{3}$, A. Shavrina ${ }^{2}$, Ja. Pavlenko ${ }^{2}$, S. Vasil'eva ${ }^{1}$ \\ ${ }^{1}$ Astronomical Observatory, Odessa National University, 65014-UA Odessa, Ukraine, \\ vfgopka@ukr.net \\ ${ }^{2}$ Main Astronomical Observatory of National Academy of Science of Ukraine, Kyiv, Ukraine \\ ${ }^{3}$ Astrocamp Contents Research Institute, Goyang, 10-329, Republic of Korea
}

\begin{abstract}
This paper presents a study of radioactive actinium in the atmospheres of stars located in galaxies with different chemical evolution history - namely, Przybylski's Star (HD 101065) in the Milky Way and the red supergiant PMMR27 in the Small Magellanic Cloud; it also reports the findings of the previous research of the red supergiant RM 1-667 in the Large Magellanic Cloud and the red giant BL138 in the Fornax dwarf spheroidal galaxy. The actinium abundance is close to that of uranium in the atmospheres of certain stars in the Milky Way's halo and in the atmosphere of Arcturus. The following actinium abundances have been obtained (in a scale of $\mathrm{lg}$ $\mathrm{N}(\mathrm{H})=12$ ): for the red supergiants PMMR27 and RM 1$667 \lg \mathrm{N}(\mathrm{Ac})=-1.7$ and $\lg \mathrm{N}(\mathrm{Ac})=-1.3$, respectively, and for the red giant BL138 $\lg \mathrm{N}(\mathrm{Ac})=-1.6$. The actinium abundance in the atmosphere of Przybylski's Star (HD $101065)$ is $\lg \mathrm{N}(\mathrm{Ac})={ }^{\prime} 0.94 \pm 0.09$, which is more than two orders of magnitude higher than those in the atmospheres of the other studied stars.
\end{abstract}

Keywords: stars: abundances - stars: abundances - actinium: atmospheres - stars: Stars: individual (PMMR27, RM_1-667, HD101065, BL138).

АНОТАЦІЯ. Започаткована авторами з 2018 року робота по дослідженню вмісту радіоактивного короткоживучого елементу актинію $(\mathrm{Z}=89)$ в атмосферах зір, що належать галактикам з різною історією хімічної еволюції. Важливою передумовою визначення вмісту актинію стала наявність теоретичних сил осциляторів, визначених в наближкнні Хатртрі-Фока (Quinet et al., 2007) і Фока-Дірака (Ürer \& Özdemir, 2012). Визначення вмісту актинію в атмосферах зір це насамперед перевірка теоретичних сил осциляторів 3 одного боку i дослідження актинію в порівнянні 3 двома іншими актиноїдами (торій і уран) 3 іншого боку. Ці три елементи є найважчі елементи, які наразі досліджуються в атмосферах зір.

На відміну від торію і урану, елементів , ізотопи яких мають довгий період піврозпаду, актиній, який має період піврозпаду всього 22.77(3) роки, ідентифікується в спектрах зір 3 деформованими сильними лініями (водню, натрію), які часто мають емісійні складові в цих лініях, що вказує на нестабільні умови в верхніх шарах атмосфери зорі.

Досліджується вміст радіоактивного актинію в атмосферах зір, які знаходяться в галактиках з різною історією хімічної еволюції (Галактика (HD101065), PMMR27 (Мала Магеланова Хмара), а також, приведені результати згідно попереднім дослідженням для червоного надгіганта RM_1-667 (Large Magellanic Clouds) i для червоного гіганта BL138 (кульова карликова галактика Форнакс). В абсолютній шкалі вміст актинію близький до вмісту урану в атмосферах деяких зір гало і в атмосфері Арктура. Отримано, для червоних надгігантів PMMR27 $\lg \mathrm{N}(\mathrm{Ac})=-1.7$ та для RM_1-667 $\lg \mathrm{N}(\mathrm{Ac})=-1.3$, для червоного гіганту BL138 $\lg \mathrm{N}(\mathrm{Ac})=-1.6$. Більш ніж на 2 порядки вміст актинію в атмосфері зорі Пшибильського (HD101065) перевищую вміст в атмосферах досліджуваних зір і дорівнює $\lg \mathrm{N}(\mathrm{Ac})={ }^{`} 0.94 \pm 0.09$ в шкалі $\lg \mathrm{N}(\mathrm{H})=12$.

\section{Introduction}

Actinium, a radioactive chemical element with atomic number 89, was discovered by Andre-Louis Debierne (Debierne, 1899) in 1899 when studying pitchblende residues (uranium ores). Actinium is one of radioactive elements with short half-lives. ${ }^{227} \mathrm{Ac}$ is the longest-lived actinium isotope, which is a member of the long decay series starting with ${ }^{235} \mathrm{U}$ and has a half-life of 21.772(3) years (Fry \& Thoennessen, 2012).

${ }^{227}$ Ac decays by $\beta$-particle emission to ${ }^{227} \mathrm{Th}$ with a probability of $98.61 \%$. Just a small fraction of ${ }^{227}$ Ac decays by $\alpha$-particle emission to francium. A series of radioactive chemical elements called the actinoids (sometimes called actinides) are named after actinium. These are 15 consecutive chemical elements in the periodic table from actinium to lawrencium with atomic numbers from 89 to 103 , respectively. Two actinoids, namely thorium $(Z=90)$ and uranium $(Z=92)$, have very long half-lives $\left(T_{1 / 2}=1.4 \cdot 10^{10}\right.$ years for ${ }^{232}$ Th and $\mathrm{T}_{1 / 2}=4.47 \cdot 10^{9}$ years for ${ }^{238} \mathrm{U}$ ); their atmospheric abundances have been extensively studied in stars assigned different spectral classes. As reported by Asplund et al. (2009), the solar photospheric abundance of thorium is $\log$ 
$\mathrm{N}(\mathrm{Th})=0.02 \pm 0.10$ while meteoritic abundances of thorium and uranium are $\log \mathrm{N}(\mathrm{Th})=0.06 \pm 0.03$ and $\log \mathrm{N}(\mathrm{U})$ $=-0.54 \pm 0.03$, respectively, on a scale of $\log \mathrm{N}(\mathrm{H})=12.0$.

Thorium abundances in the atmospheres of metal poor stars vary from -3.1 to +0.5 (Ren et al., 2012). The thorium and uranium abundances in the atmosphere of Arcturus are $\log \mathrm{N}(\mathrm{Th})=-0.35$ and $\log \mathrm{N}(\mathrm{U})=-1.05$, respectively (Gopka et al., 1999). In the halo giant CS 31082 001 (Hill et al., 2002), the thorium and uranium abundances are $\log \mathrm{N}(\mathrm{Th})=-0.09$ and $\log \mathrm{N}(\mathrm{U})=-1.98$, respectively. For the bright halo red giant HD22117, log $\mathrm{N}(\mathrm{Th})=-1.50$ was obtained in the dissertation by $\mathrm{V}$. Yushchenko by spectrum synthesis technique applied to the spectral data acquired with 1.93-metre telescope at the Haute-Provence Observatory. Ivans et al. (2006), by employing spectra obtained with more powerful telescopes, reported the thorium abundance $\log \mathrm{N}(\mathrm{Th})=-1.58$. The uranium abundance $\log \mathrm{N}(\mathrm{U})=<-2.02$, determined for HD22117 using spectra obtained with 2-metre telescope at the Peak Terskol Observatory in the dissertation by $\mathrm{V}$. Yushchenko (Heavy Elements in the Atmospheres of Peculiar Stars, 2017), is virtually similar to the value reported in the study by Hill et al. (2002).

For quite a long time, the issues related to all the other actinoids were left unaddressed in spectroscopic surveys of stars.

\section{Actinium as the subject of spectroscopic research}

Przybylski's star. Actinium as the subject of spectroscopic research garnered attention after 2004 (Gopka et al., 2004). It was discovered that the observed wavelengths of some lines in the spectrum of chemicallypeculiar magnetic Przybylski's Star, which could not be identified with traditional absorption lines, currently under investigation, coincided with those of chemical elements with atomic number $Z>83$, including absorption lines of actinium. The findings reported in 2004 were corroborated in a later study by Gopka et al. (2008) (Fig1). The results of computations of oscillator strengths of neutral and singly-ionised actinium conducted using a semi-empirical relativistic Hartree-Fock approach, including core polarisation effects, were reported in 2007 (Quinet et al., 2007). The oscillator strengths calculated for singly-ionised actinium using a fully relativistic multiconfiguration DiracFock (MCDF) method were presented in 2012 (Ürer \& Özdemir, 2012). The foregoing findings laid the groundwork for quantitative analysis of the actinium abundance in stellar atmospheres.

The actinium abundance in the atmosphere of Przybylski's Star was reported in the dissertation by V. Yushchenko (Heavy Elements in the Atmospheres of Peculiar Stars, 2017). The resulting values are given in Table 1, which has the following columns: wavelength $(\lambda)$, atomic number of the chemical element $(\mathrm{Z}=89)$, identification of the chemical element (Ident.), equivalent width of the identified line (Eq.W.), low-lying energy levels $\left(\mathrm{E}_{\mathrm{low}}\right)$ and elemental abundance $(\log N)$.

The highest value of the actinium abundance in stellar atmospheres determined so far is $\lg \mathrm{N}(\mathrm{Ac})=0.94 \pm 0.09$ on a scale of $\log \mathrm{N}(\mathrm{H})=12$; this value was obtained using a model of Przybylski's Star with $\mathrm{T}_{\text {eff }}=6,600 \mathrm{~K}$; $\log \mathrm{g}=4.0$ and $\mathrm{V}_{\mathrm{mi}}=3.5 \mathrm{~km} \cdot \mathrm{s}^{-1}$.
Table 1. The actinium abundance in the spectrum of Przybylski's Star.

\begin{tabular}{cccccc}
\hline $\begin{array}{c}\lambda \\
(\AA)\end{array}$ & Ident. & $\begin{array}{c}\text { Eq.W.W. } \\
(\mathrm{m} \AA)\end{array}$ & $\begin{array}{c}\mathrm{E}_{\text {low }} \\
(\mathrm{eV})\end{array}$ & $\log$ gf & $\log \mathrm{N}$ \\
\hline \hline 3043.300 & Ac II & 25 & 1.127 & 0.19 & 1.059 \\
3164.810 & Ac II & 20 & 0.653 & -0.13 & 0.809 \\
4168.400 & Ac II & 25 & 0.653 & -0.40 & 0.930 \\
5910.850 & Ac II & 24 & 0.653 & -0.60 & 0.963
\end{tabular}

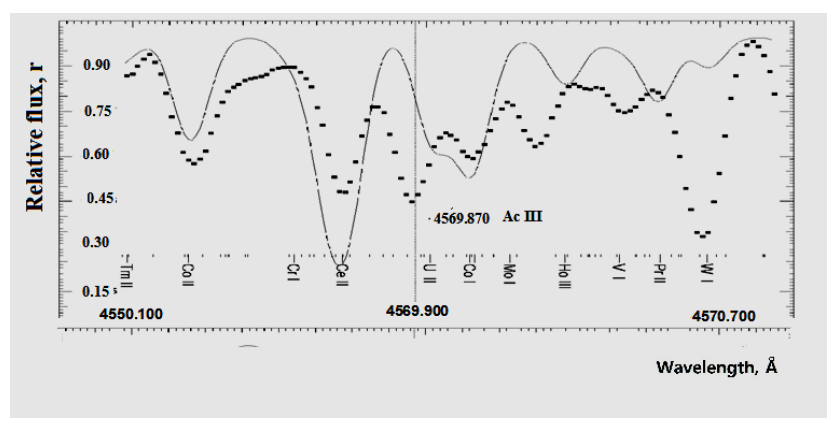

Figure 1: The observed spectrum at wavelength of nonidentified line in the spectrum of chemically-peculiar magnetic Przybylski's star coincided with wavelength of chemical elements actinium AcIII $\lambda$ 4569.879 $\AA$ (Gopka et al., 2008).

The red supergiant PMMR27 in the Small Magellanic Clouds $\left(\mathrm{v}=13.2^{\mathrm{m}}\right)$. Apart from Przybylski's Star, the actinium lines are identified in the spectra of stars that have already gone through certain stages of their evolution and belong to galaxies with different history of their enrichment with heavy elements: in the Magellanic Clouds, the most effective contribution is made by r-process elements (Gopka et al., 2018a) while in a dwarf spheroidal galaxy, it is asymptotic giant branch (AGB) medium mass stars that play an important role by enriching it with s-process elements (Gopka et al., 2018b).

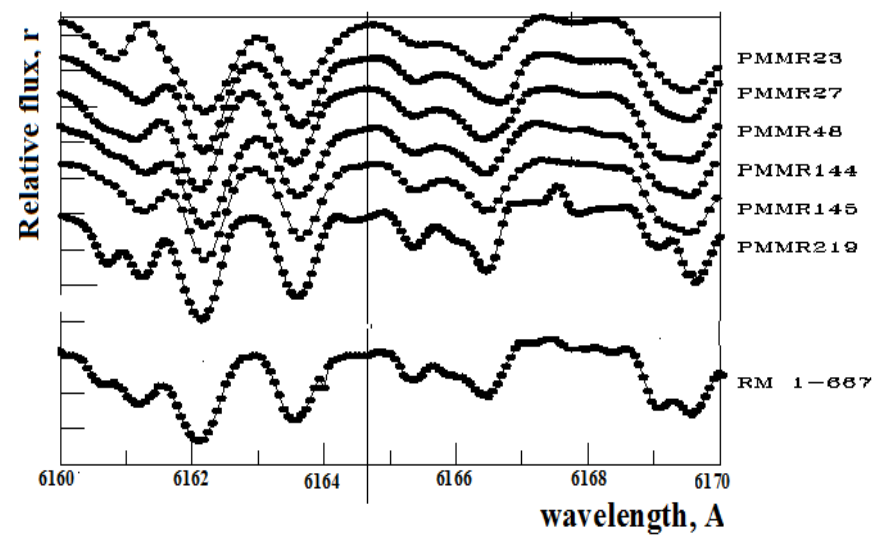

Figure2: Portions of spectra of red supergiants in the Small Magellanic Cloud (PMMR23, PMMR27, PMMR48, PMMR144, PMMR145 and PMMR219) and the red giant in the Large Magellanic Cloud, RM 1-667, in the region of the Ac II line at $6164.75 \AA$. The spectra shifted a given value with respect to each other. 
The observation of the K-supergiants in the Magellanic Cloud was carried out by Hill (1997) at the European Southern Observatory (ESO) at La Silla. The spectral resolution of the spectra was near 20000 and 30000 , the range of wavelengths is 5900-7100 $\mathrm{A}^{\circ}$. The red supergiant PMMR23 is located in a region of the Small Magellanic Cloud (SMC) where velocities of stars and surrounding gas are far lower than those in other regions of SMC, thus yileding the profile of the $\mathrm{H} \alpha$ line slightly deformed. A peak can be seen where the actinium line should be positioned, but no line is observed. On the contrary, radial velocities of all the other supergiants, namely PMMR27, PMMR48, PMMR144, PMMR145 and PMMR219, as well as those of the surrounding gas, are higher, which is reflected in the profile of the $\mathrm{H} \alpha$ line in the form of emission components in the $\mathrm{H} \alpha$ line wings. For those stars as can be seen in Fig. 2, weak lines can be observed at the wavelength $6164.75 \AA$.

The red supergiant RM 1-667 $\left(\mathrm{v}=13.1^{\mathrm{m}}\right)$ is a member of the Large Magellanic Cloud (LMC) population; it exhibits strongly deformed profile of $\mathrm{H} \alpha$ with an emission component in the short-wavelength and central portion of the spectrum, which indicates that some specific high-energy processes take place in the upper atmosphere of this supergiant (Gopka et al., 2018a). The actinium lines are identified unambiguously at the wavelength $\lambda 6164.75 \AA$ and $\lambda 5910.85 \AA$, the actinium abundance: $\log \mathrm{N}($ Ac $)=-$ 1.3 on a scale of $\lg \mathrm{N}(\mathrm{H})=12$ (Gopka et al., 2018a).

In this work, two lines of ionized actinium AcII at wavelengths $\lambda 5910.85 \AA$ and $\lambda 6164.75 \AA$, the strongest lines in the visible part of the spectrum, are invistigated in the spectrum of the red supergiant PMMR27. The supergiant PMMR27 is located in the region of the Small Magel-

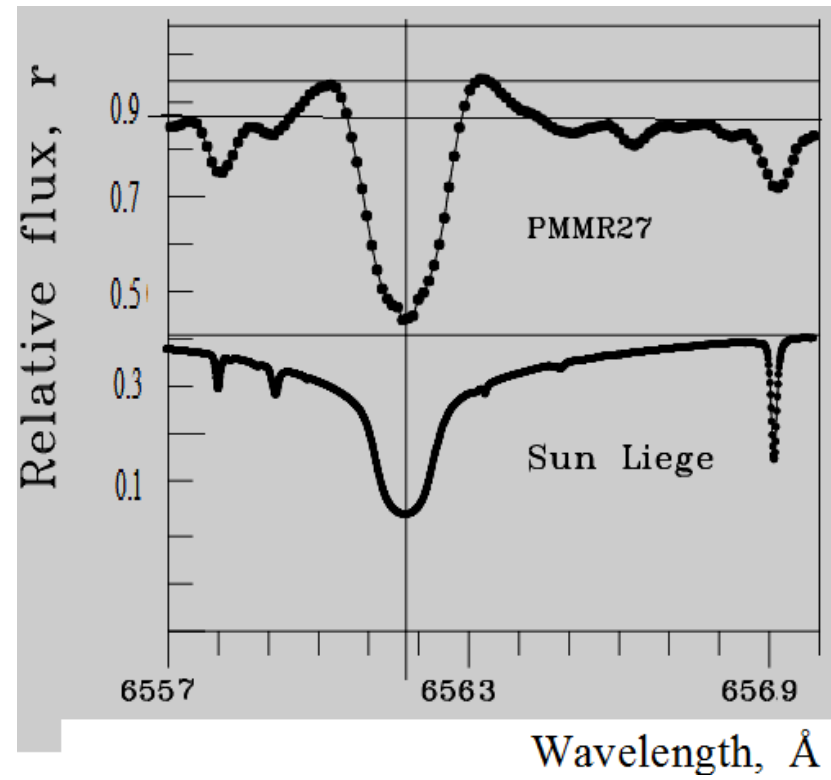

Figure 3: A comparison of the observed profile of the hydrogen $\mathrm{H} \alpha \lambda 6562.797 \AA$ in the spectrum of the red supergiant PMMR27 with observed profile of the hydrogen $\mathrm{H} \alpha$ in the spectrum of the Sun (Delbouille et al., 1973). The spectra shifted a given value along the vertical axis with respect to each other. lanic Cloud with an increased redial velocity of stars and increased velocity the surrounding gas around such stars. Observations from a 3.6 -meter telescope were used (Hill, 1997). As mentiond above, such stars are characterrized by hydrogen profiles with the presence emission components (Fig. 3).

Such line profiles are reproduced taking into account the higher temperature in the higher layers of the atmosphere model compared to the lower ones, which allows us to make assumptions about the course of some highenergy accretion processes in such atmospheres.

In the study of the actinium abundances in the atmosphere PMMR27 used a model with parameters $\mathrm{T}_{\text {eff }}=$ $4,250 \mathrm{~K} ; \log \mathrm{g}=0.0$ and $[\mathrm{Fe} / \mathrm{H}]=-0.5, \mathrm{~V}_{\mathrm{mi}}=3.5 \mathrm{~km}^{\cdot} \mathrm{s}^{-1}$, $\mathrm{V}_{\mathrm{ma}}=4.0 \mathrm{~km} \cdot \mathrm{s}^{-1}$, which are not differs significantly from the accepted parameters of the star's atmosphere in work by Hill (1997).

Equivalent width of the ionised actinium line Ac II at wavelength $\lambda 5910.85 \AA$ is $15 \mathrm{~m} \AA$, which corresponds to the actinium abundances $\log \mathrm{N}(\mathrm{Ac})=-1.7$ using the Kuruch program WIDTH-9. Syntetic spectrum was used to calculate the content using the model with $\mathrm{T}_{\mathrm{eff}}=4,250$ $\mathrm{K}$; $\log \mathrm{g}=0.0$ and $[\mathrm{Fe} / \mathrm{H}]=-0.5, \mathrm{~V}_{\mathrm{mi}}=3.5 \mathrm{~km} \cdot \mathrm{s}^{-1}, \mathrm{~V}_{\mathrm{ma}}=$ $4.0 \mathrm{~km} \cdot \mathrm{s}^{-1}$, from the grid of models calculated by Castelli and Kuruch (Castelli \& Kurutz, 2004).Using the program URAN (Yushchenko, 1997) obtained the best fit with the smallest deviation $\log \mathrm{N}(\mathrm{Ac} / \mathrm{H})=-1.7 \pm 0.5$ from the best approximation \pm 0.5 . The errors of the actinium abundances determinated for this line are equal to: when the temperature decreases by $\Delta \mathrm{T}=100 \mathrm{~K}$ than $\Delta \log \mathrm{N}(\mathrm{Ac})=$ $0.2 \mathrm{dex}$; with increasing acceleration of gravity by $\Delta \log g=0.2, \Delta \log N(\mathrm{Ac})=-0.03 \mathrm{dex}$; with increasing turbulent velocity by $\Delta 1 \mathrm{~km} \cdot \mathrm{s}^{-1} \Delta \log \mathrm{N}(\mathrm{Ac})=-0.18 \mathrm{dex}$. The line is quite sensitive to changes in the content of actinium , as seen in Figure 4. The percentage contribution of the AcII line at wavelength $\lambda 5910.85 \AA$, given the maximum number of line of elements with known oscillator strenghs, including weak line lines, more than 80 percent. According to Quinet et al. (2007), the intensity of the actinium line at wavelength $\lambda 6164.75 \AA$ is weaker than the line at the wavelength $\lambda 5910.85 \AA$. Indeed, in the spectrum of the red giant PMMR27 we can estimate the upper limit on tof the actinium content equal to $\log \mathrm{N}(\mathrm{Ac} / \mathrm{H})=-$ 2.0, using the line $\lambda 6164.75 \AA$.

Synthetic spectrum calculation were performed using various programs. Figure 5 compares the spectrum of the red supergiant PMMR 27 with synthetic spectrum calculated using program SYNTHV (Tsymbal 1996, 2012 version) with atomic data from the VALD-3 database VALD-3 (Ryabchikova et al., 2011) and the array of molecular lines formed by Tsymbal (1996) (Fig. 5). The PMMR 27 spectrum obtained with a resolution 20, 000 and an individual model were used (Pavlenko, 1997, 2003). Content calculations for this line $\lambda 6164.75 \AA$ for spectrum with spectral resolution 20,000 confirmed result for that with spectral resolution of 30, 000 using the URAN program (Yushchenko, 1997) and the model with $\mathrm{T}_{\text {eff }}=4,250 \mathrm{~K} ; \log \mathrm{g}=0.0$ and $[\mathrm{Fe} / \mathrm{H}]=-0.5, \mathrm{~V}_{\mathrm{mi}}=3.5$ $\mathrm{km} \cdot \mathrm{s}^{-1}, \mathrm{~V}_{\mathrm{ma}}=4.0 \mathrm{~km} \cdot \mathrm{s}^{-1}$ from the Castelli and Kurucz grid model (Castelli \& Kurucz, 2004). 


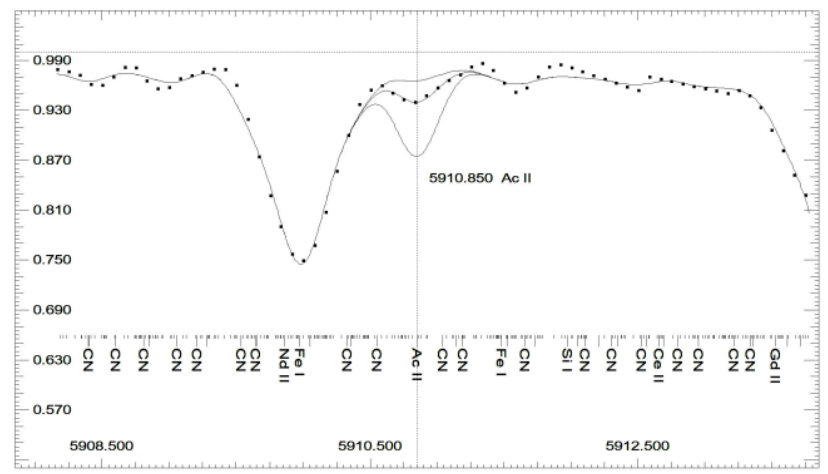

Figure 4: A comparison of the observed spectrum of the red supergiant PMMR27 in the Small Magellanic Cloud in the region of the ionised actinium line $\lambda 5910.85 \AA$ with synthetic spectra, using program URAN (Yushchenko, 1997) for three different abundance values adjusted to the best fit with the smallest deviation from the best approximation \pm 0.5 : $\log \mathrm{N}(\mathrm{Ac} / \mathrm{H})=-1.7 \pm 0.5)$. Spectral resolution of spectrum PMMR27 is 30000 (Hill, 1997).

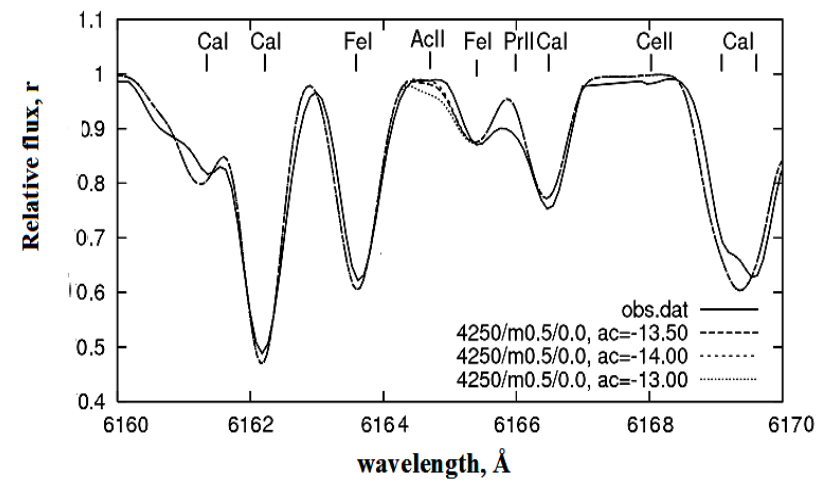

Figure 5: A comparison of the observed spectrum of the red supergiant PMMR27 in the Small Magellanic Cloud in the region of the ionised actinium line $\lambda 6164.75 \AA$ with synthetic spectrum for three different abundance values adjusted to the best fit with the smallest deviation from the best approximation $\pm 0.5: \log \mathrm{N}(\mathrm{Ac} / \mathrm{H})=-2.0 \pm 0.5$. Using the program SYNTHV (Tsymbal, 1996). Spectral resolution of spectrum is 20000 (Hill, 1997).

The red giant BL138 from Fornax dwarf spheroidal galaxy. But equivalent width of the ionised actinium line at the wavelength $\lambda 6164.75 \AA$ is not weak in the spectrum of red giant BL138, which is located in the Fornax dwarf spheroidal galaxy (Gopka et al., 2018b). Equivalent width of the ionised actinium line Ac II at wavelength $\lambda 6164.75$ $\AA$ is $14 \mathrm{~m} \AA$. The actinium abundance in the atmosphere of the red giant BL138 is close to the above indicated value: $\log \mathrm{N}(\mathrm{Ac} / \mathrm{H})=-1.6 \operatorname{dex}($ Gopka et al., 2018b).

\section{Conclusions}

Actinium is the third element of the actinoid series currently studied in stellar atmospheres. The actinium abundance in the atmospheres of the target stars does not differ significantly from the uranium abundance in the atmospheres of certain stars in the Milky Way's halo. Radioactive ${ }^{227} \mathrm{Ac}$ with a half-life of 21.772(3) years observed in stellar spectra indicates that this chemical element is produced through a certain synthesis process, which is sustained over time. The presence of actinium in stellar atmospheres is an explicit indication of unstable atmospheric physical conditions, which are caused by a number of factors and do not depend on the chemical evolution of the galaxy wherein the respective stars are located.

The actinium absorption lines have been identified in the spectra of several sample stars at different evolutionary stages that are located in galaxies with different chemical evolution history.

The actinium absorption lines at the wavelengths $\lambda 5910.85 \AA$ and $\lambda 6164.75 \AA$ have been identified in the spectra of stars that exhibit anomalous profile of $\mathrm{H} \alpha$ lines and/or other strong lines of chemical elements, such as sodium. Note that actinium $\left({ }^{227} \mathrm{Ac}\right)$ with the longest halflife of 21.772(3) years is produced via radioactive uranium decay series that yields the doubly-magic nuclide ${ }^{208} \mathrm{~Pb}$ as the end product. As mentioned in a number of studies (Serminato et al., 2009; Käppeler et al., 2011), "according to the classical analysis of the s-process, the abundance distribution in the Solar System is recognised as a combination of three components: the main component (accounting for s-process isotopes in the range from A 90 to $\mathrm{A}<208$ ), the weak component (accounting for s-process isotopes up to A 90) and the strong component, introduced to reproduce about $50 \%$ of doubly-magic ${ }^{208} \mathrm{~Pb}$ ". Therefore, it is of great importance to examine atmospheres of some stars to determine abundances of such radioactive chemical elements as actinium, as well as those of other elements similar to actinium, which may serve as sources of additional production of ${ }^{208} \mathrm{~Pb}$.

\section{References}

Asplund M. et al.: 2009, ARA\&A, 47, 481.

Castelli F. \& Kurucz R. : 2004, ArXiv Astrophysics eprints astro-ph/0405087.

Debierne A.-L.: 1899, Comptes Rendus Acad. Sci. 129, 593.

Delbouille L., Roland G., \& Neven L. 1973, Photometric Atlas of the Solar Spectrum from $\lambda 3000$ to $\lambda 10000$, Liége: Institut d'Astrophysique de l'Université e de Liége.

Ivans V. et al.: 2006, ApJ, 645, 613.

Fry C. \& Thoennessen M.: 2012, eprint arXiv:1205.5844 http://eprintweb.org/s/article/nuclex/1203.1194.

Gopka V., Yushchenko A., Shavrina A. et al.: 2004, IUE 224, 734 .

Gopka V., Yushchenko A., Yushchenko V. et al.: 2008, KPHNT, 2008, 24, 89.

Gopka V., Shavrina A., Yushchenko V. et al.: 2018a // KPhNT, 34, 12.

Gopka V., Yushchenko A., Yushchenko V. et al.: 2018b. PhST, 5, ISSN2409-6121, 70.

Hill V.: 1997, A\&A, 324, 435

Hill V., Plez B., Cayrel R.: 2002, A\&A, 387, 560.

Käppeler F. et al.: 2011. Rev. Mod. Phys. 83, 157.

Pavlenko, Ya. V.: 1997, A\&ASci, 253, 43.

Pavlenko, Ya. V.: 2003, Astronomy Reports, 47, 59.

Quinet P. et al.: 2007. A\&A, 474, 307.

Ren J., Christlieb N., Zhao G.: 2012, A\&A, 537, A118.

Ryabchikova T. et al.: 2011, Учен. зап. Казан. ун-та, 153, 61.

Serminato A. et al.: 2009, PASA, 26, 153.

Tsymbal V., 1996, ASP Conf. Ser., 108, 198.

Ürer G \& Özdemir L.: 2012, J. Kor. Phys. Soc. 61, 353.

Yushchenko A.V.: 1997, in Proc. of the 20th Stellar Conference of the Czech and Slovak Astronomical Institutes. P. 201. 